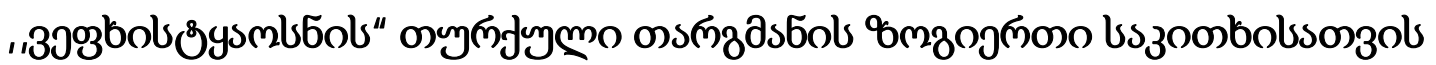

\author{
6ojsosdj 6mbs

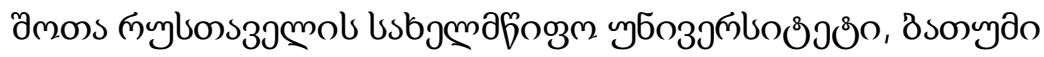 \\ https://doi.org/10.52340/idw.2021.511
}

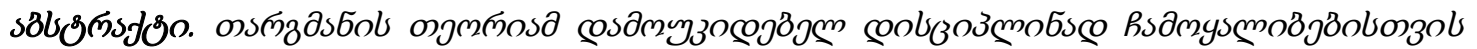

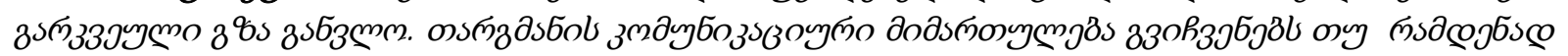

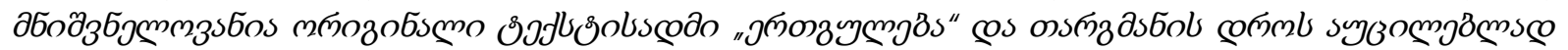

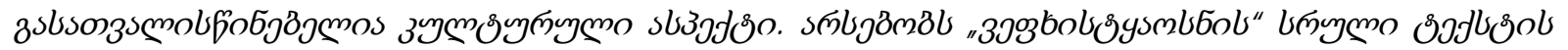

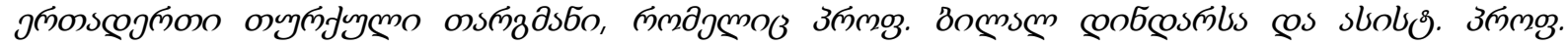

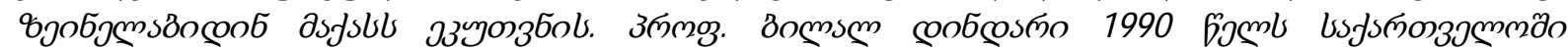

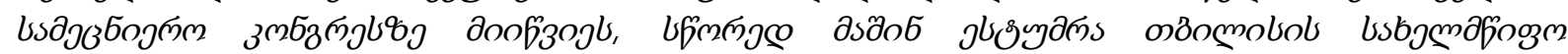

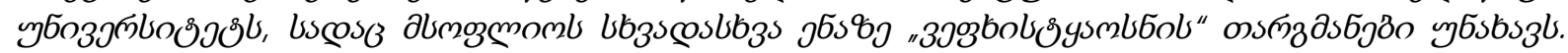

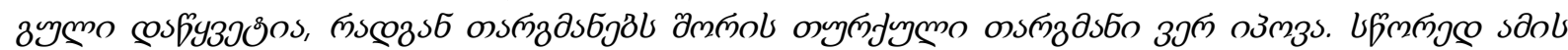

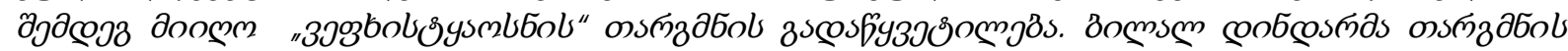

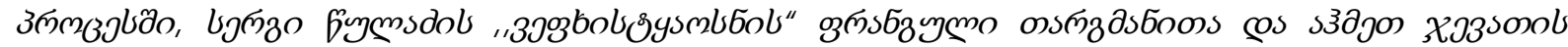

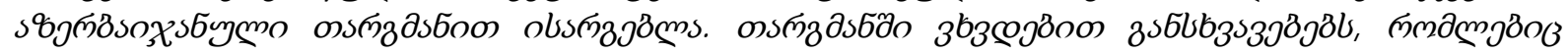

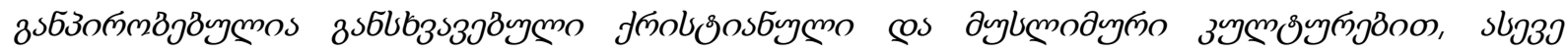

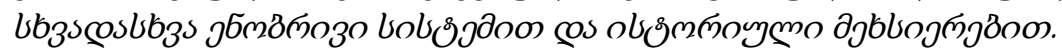

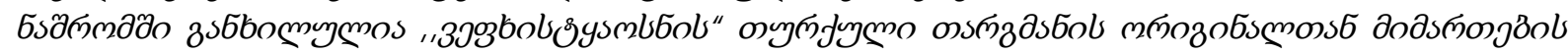

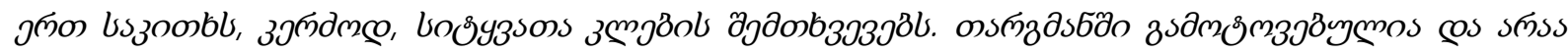

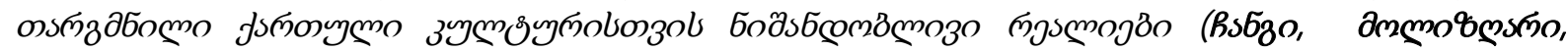

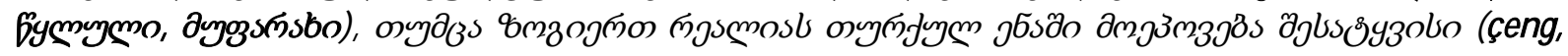

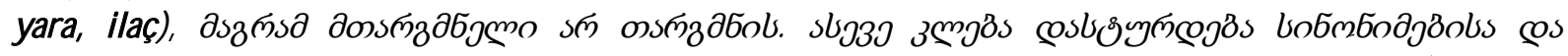

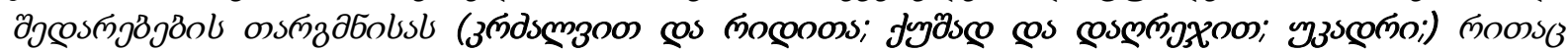

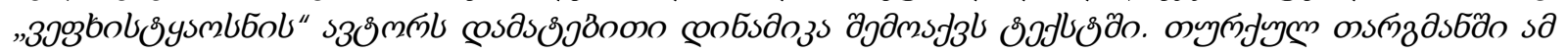

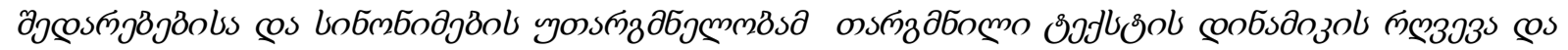

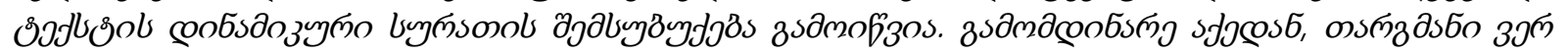

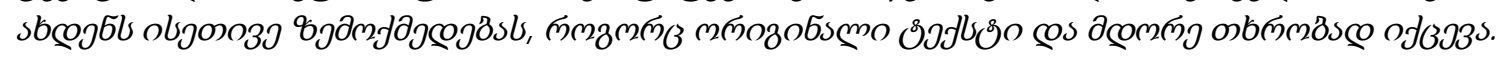

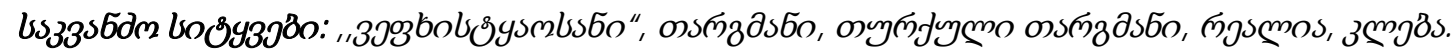

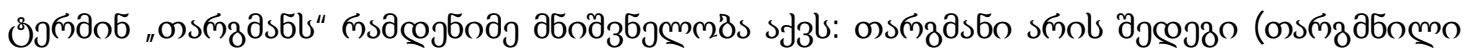

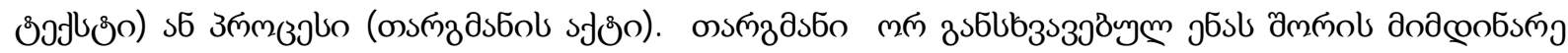

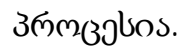

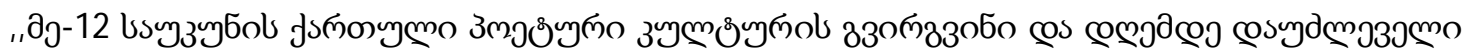

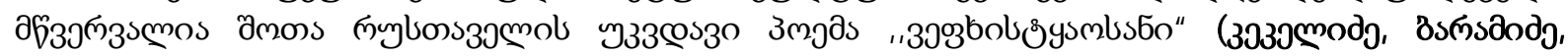
1987:246).

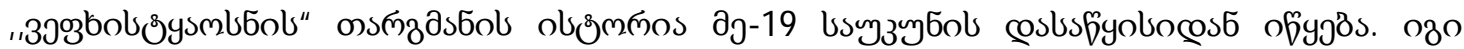

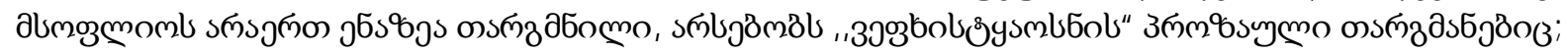




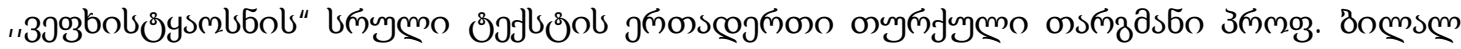

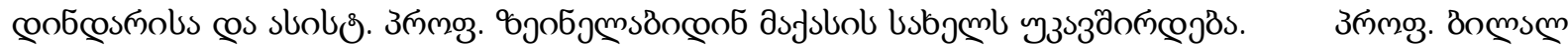

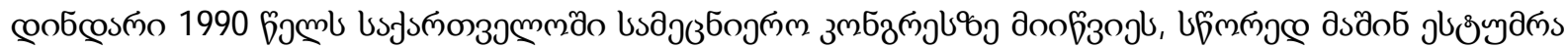

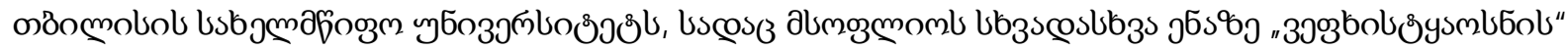

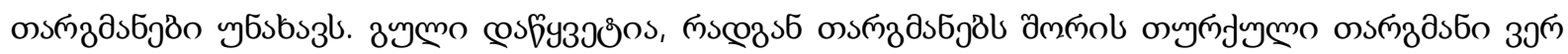

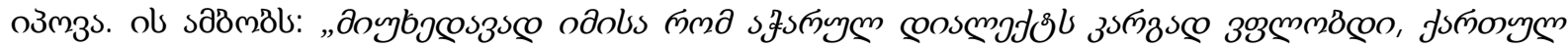

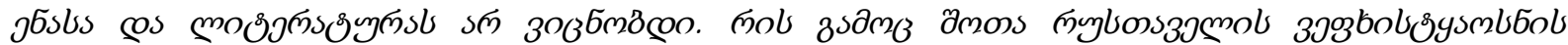

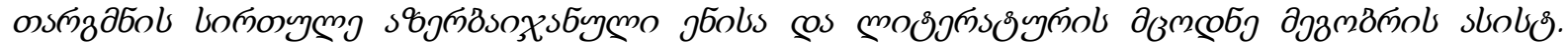

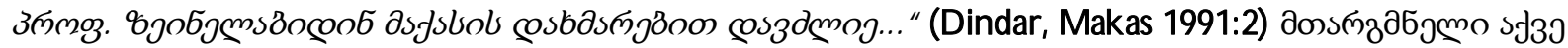

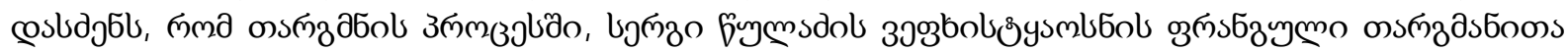

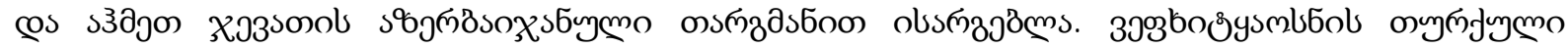

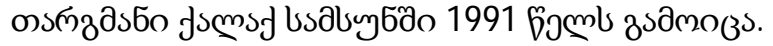

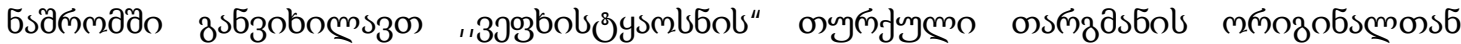

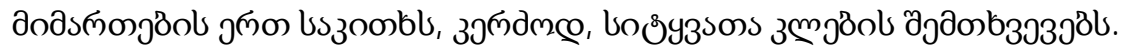

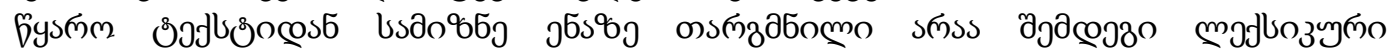

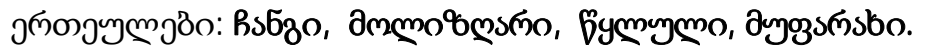

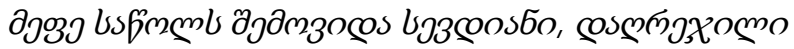

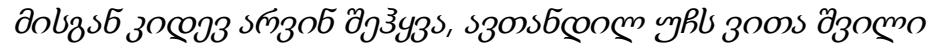

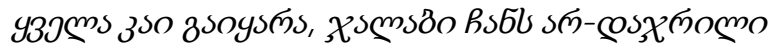

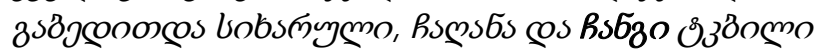

Şah çekildi makamina, ası surat, kalbi yara,

Yalnız Aftandil mahremdi, başkası girmedi ora.

Dağıldı tüm derber ehli, toplanmadı çoluk-çocuk,

Şahın keyfi düzelmedi; yürek sanki bir bir pare.

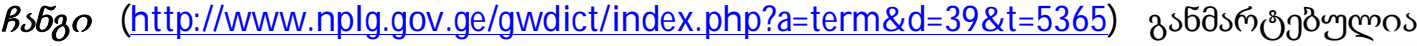

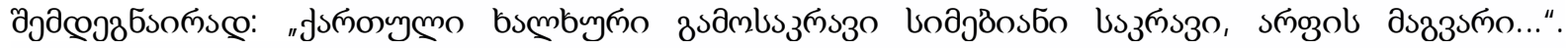

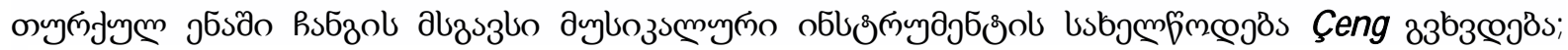
"A çık arplardan köşeli arplar grubuna giren çalgıdır... Benzer çalgılar İran'da Chang, Gürcistan'da

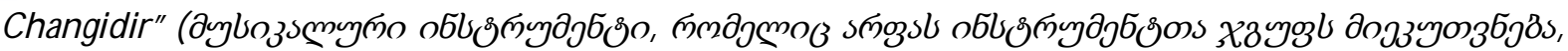

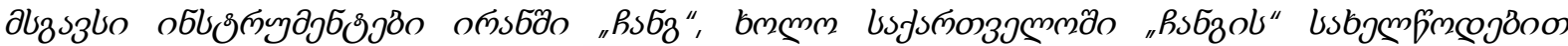

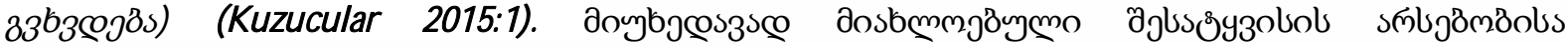

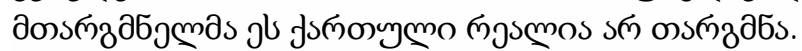

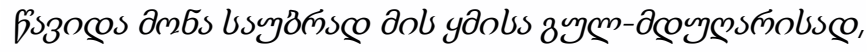

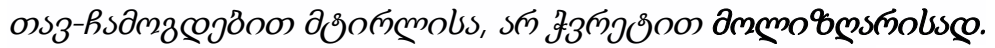

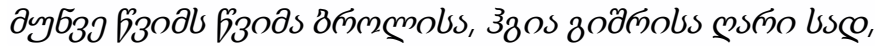

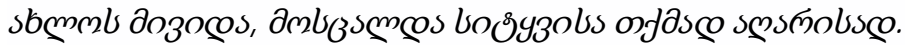

Bir kul ona yanaştı ki, bilsin acep nedir derdi,

Hayal aleminde gördü gözü yaşll cengaveri.

Kara gözler akıttyor billur gibi katreleri,

Kul düşündü: Onunla konuşmanın değil yeri.

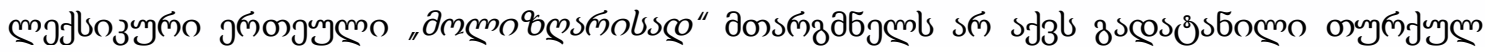

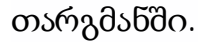

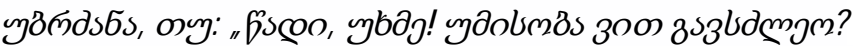

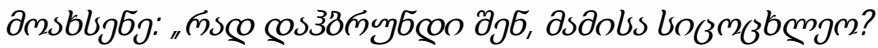

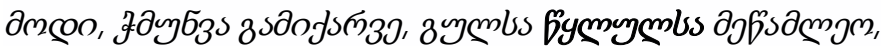




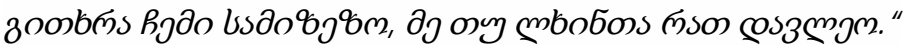

Şah buyurdu: Çağır gelsin, ondan ayrı yaşıyamam,

Kızım niye geri döndü, tez sor benim hayatımdan.

Gel derdimi arz edeyim, sen de iyi dinle bari,

Kurtar beni dertlerimden, ümit üzmeyim canımdan.

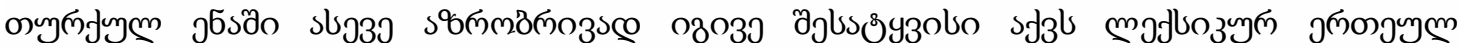

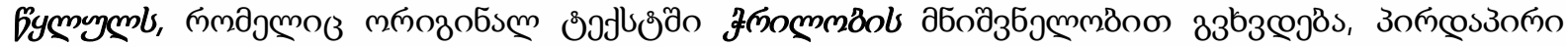

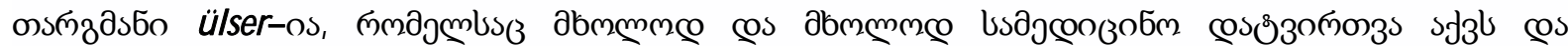

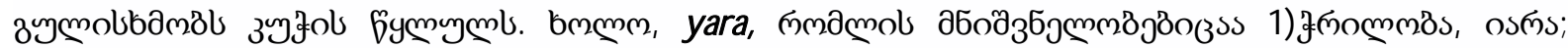

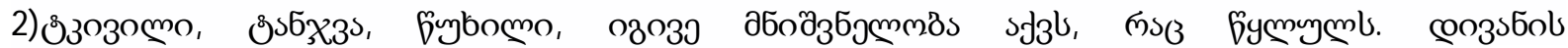

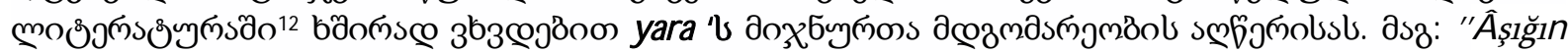

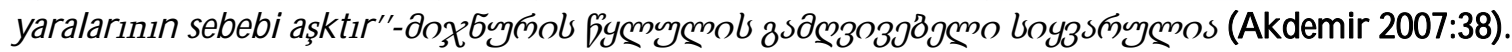

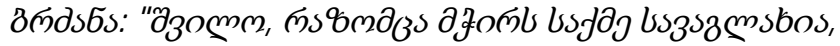

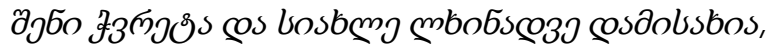

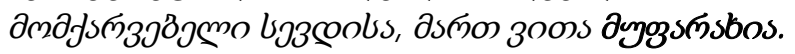

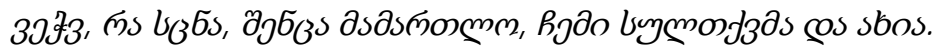

Şah buyurdu: Çok haklısın, gamın esiridir gönlüm,

Kalbimin tek tesellisi, her sevincim sensin benim.

Sen görünce gam dăglır...lakin benim ah-nalemin

Sebebini bilmiş olsan, hak verirsin, ey güzelim!

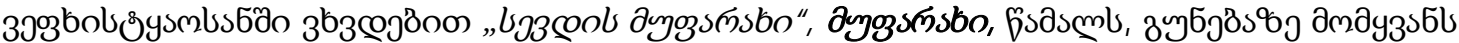

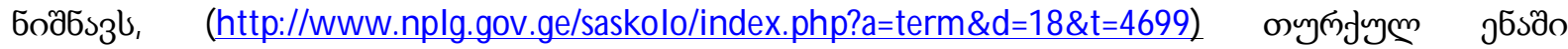

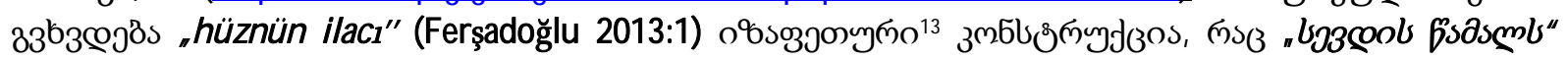

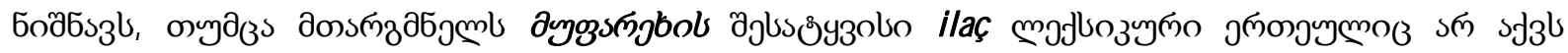

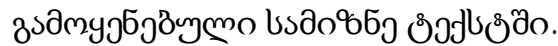

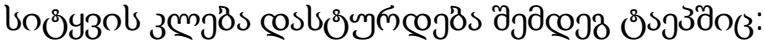

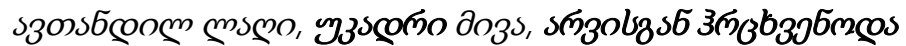

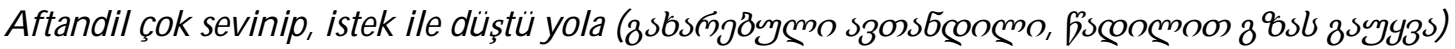

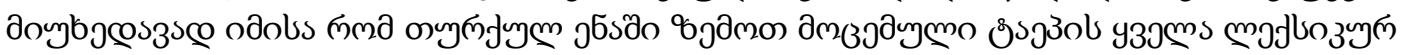

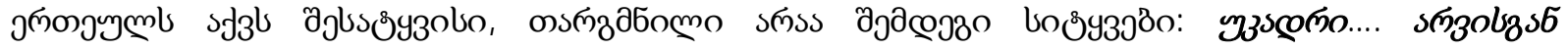

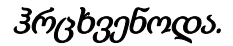

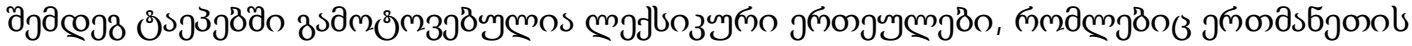

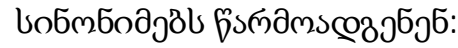

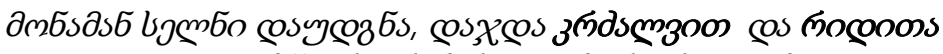

Hizmetçinin getirdiği iskemlede kumandanlar kumandanı

Oturarak sevinç ile seye dald nazl yari.

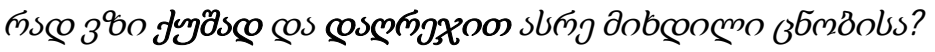

Sebebini bilir misin kalbimdeki bu mihretin?

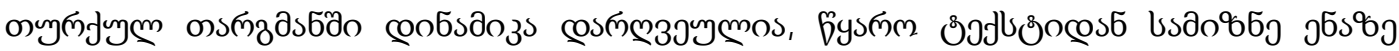

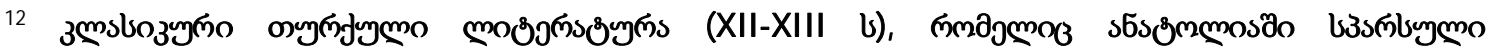

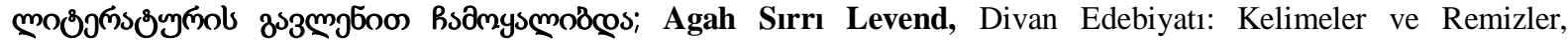
Mazmunlar ve Mefhumlar, İstanbul, 2017, 33. 13-15.

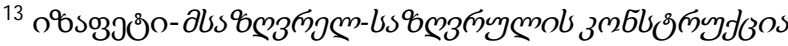




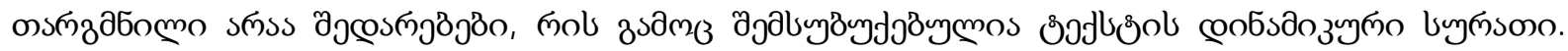

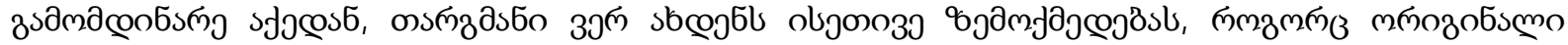

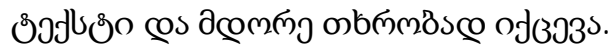

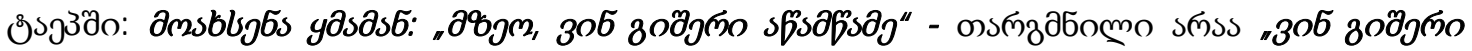

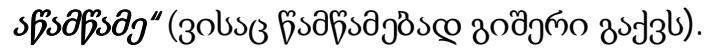

Oh! Güneşim benim! Diye, cevap Verdi koç Aftandil.

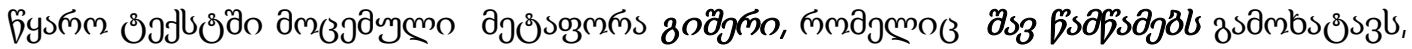

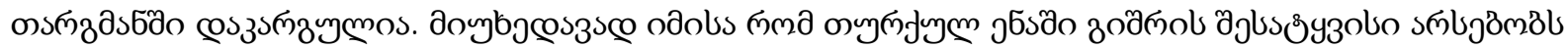

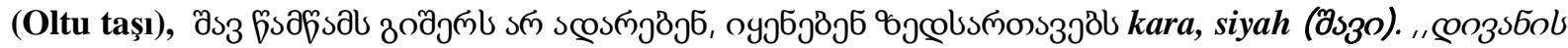

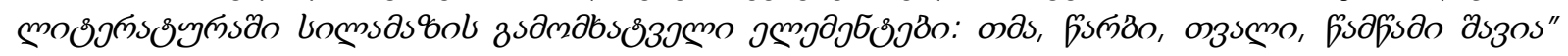
(Sefercioğlu, 2017:142).

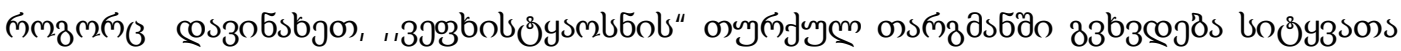

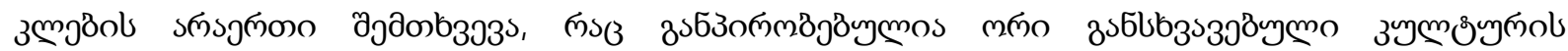

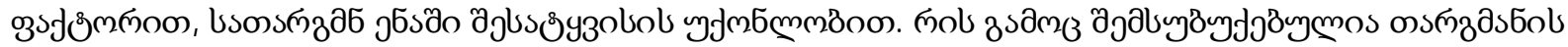

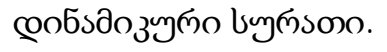

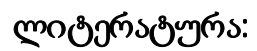

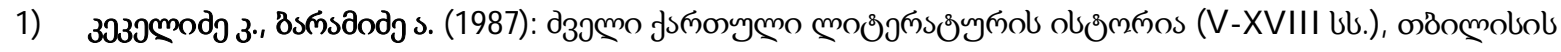

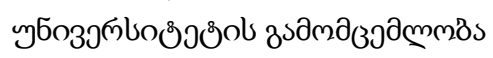

2) A kdemir, A. (2007): Divan Şi irinde "Cünûn" ve "M ecnûn" Kavramları ile Bu Kavramların Fehîm-i Kadîm Dîvânı'ndaki Kullanımı, bilig , A hmet Y esevi Üniversitesi M ütevelli Heyet Başkanlığı, Bahar, sayı 41

3) Agah Sirrı Levend, (2017): Divan Edebiyatı: Kelimeler ve Remizler, Mazmunlar ve Mefhumlar, İstanbul,

4) Dindar B., Makas Z. (1991): (Çeviri) Kaplan Postlu Şövalye; Eser Matbaasi, Samsun

5) Ferşadoğlu, S. (2013): Hüznün ilâcı, kederin düşmanı https://www.yeniasya.com.tr/saliha-fersadoglu/huznunilaci-kederin-dusmani 210049

6) Kuzucular, Ş. (2015): Çeng ve Çengi ( Divan Şiirinde Çeng ve Çengi)

7) Sefercioğlu, N. (2012): "Yazı ve Yazı İle İlgili Unsurların Divan Şiirinde Kullanılışı”.ErişimTarihi:17.08.2012 https://docplayer.biz.tr/28687895-Yazi-ve-yazi-ile-ilgili-unsurlarin-divan-siirinde-kullanilisi.html

\title{
"The Knight of the Panter's Skin" - Some Issues of the Turkish Translation
}

\author{
Nikabadze Nona \\ Shota Rustaveli State University, Batumi
}

\begin{abstract}
Translation theory has gone some way towards becoming an independent discipline. The communicative direction of translation shows the importance of " fidelity " to the original texts and it is also essential to consider its cultural aspect. There is only a single completed Turkish translation of "The Knight in the Panther's Skin", which was translated by Dr Bylal Dindar and Dr Zeynelabidin Makas. In 1990, Dr Byblal Dindar was invited to Georgia for the scientific congress. It was then that he went to the Tbilisi State University where he discovered the different world language translations of "The Knit of the Panter's Skin". He became wistful when he could not find the Turkish translation. He thus decided to translate the poem into Turkish.In the translation process, Dr. Bylal Dindar utilized the French and Azeri translations of "The Knight in the Panther's Skin" translated by Sergi Tsuladze (French) and Ahmet Jevat (Azeri). The two translations are different, which is due to the differences between Christian and Muslim cultures, as well as different language systems and historical memory.

The research discusses a topic of the Turkish translation of "The Knight in the Panther's Skin", in particular, the occasions of the word absences. Translation misses and does not translate
\end{abstract}


the important Georgian realis (Changi, Molizghari, Tskluli, Mufarexi), The translation is missing and does not translate the important Georgian realis (Changi, Molizghari, Tskluli, Mupharexi), unless some of these realis have a Turkish equivalent (çeng, yara, ilaç), but the translator does not provide a translation. Similarly, the word omitting is confirmed in the synonyms and in the translation of the comparatives (Krdzalvit and Ridit, Qushad and Daghrejit, Ukadri), beneath which the author of "The Knight in the Panther's Skin" introduces another dynamism into the poem. This is why the Turkish translation has lost its dynamism while these synonyms and comparatives are not translated at all, thus simplifying the image of the dynamism of the text. Therefore, the Turkish translation does not have the same influence as the original text and is obscured to retell.

Keywords: "The Knight in the Panther's Skin", Translation, Turkish Translation, Realis, Omitted 